\title{
Prediction of genetic gain in Ficus variegata progeny trial based on breeding value
}

\author{
LILIEK HARYJANTO^, PRASTYONO, YAYAN HADIYAN, MUDJI SUSANTO \\ Centre for Forest Biotechnology and Tree Improvement. Jl. Palagan Tentara Pelajar Km. 15, Purwobinangun, Pakem, Sleman 55582, Yogyakarta, \\ Indonesia. Tel.: +62-274-895954, Fax: +62-274-896080. `email: liek_ht@yahoo.com
}

Manuscript received: 10 May 2019. Revision accepted: 18 September 2019.

\begin{abstract}
Haryjanto L, Prastyono, Hadiyan Y, Susanto M. 2019. Prediction of genetic gain in Ficus variegata progeny trial based on breeding value. Biodiversitas 20: 2994-2999. Prediction of genetic gain in Ficus variegata Blume progeny trial based on breeding values. The aim of this study was to estimate the breeding value based on components variance and genetic gain prediction of Ficus variegata Blume using REML/BLUP. A total of 17 families of Ficus variegata Blume were evaluated at three years after planting at progeny trial in Mangunan, Bantul, Yogyakarta laid out in Randomized Completely Block Design (RCBD). Estimation of variance family (height and diameter) were $\pm 5 \%$ of total variance. Narrow-sense individual heritability was moderate $(0.27$ and 0.21 respectively) indicated promising genetic improvement. Strong genetic correlation of height and diameter ( $\left.\mathrm{r}_{\mathrm{G}}=0.9\right)$ indicated that improving a trait will improving others. BLUP analysis for diameter trait showed that the best individual value from best family selection was appropriated with restriction 10 family and 5 individual per family and genetic gain prediction was $15.83 \%$ gave acceptable rate of inbreeding $2 \%$ per generation.
\end{abstract}

Keywords: Ficus variegata Blume, heritability, inbreeding, selection, variance component

\section{INTRODUCTION}

A pioneer and fast-growing tree species of Ficus variegata Blume (Moraceae) is naturally distributed in Southeast Asia, India, Japan, China, Taiwan, Australia and the Pacific Islands (Zhekun and Gilbert 2003). The F. variegata trees are generally large and can reach a height of 25 meters and starts to bear fruit after the age of 3 years. Mature trees are cauliflorous, bearing abundance of figs on the trunk, branches, and stems (Spencer et al. 1996; Kuaraksa et al. 2012). Syconia fruits are generally developed in dense clusters. Mature fruits are about 30-40 $\mathrm{mm}$ in diameter (Spencer et al. 1996). The young fruit is green, then turn into yellow and finally become red once it is ripe. F. variegata is pollinated by an aganoid wasp (Spencer et al. 1996).

The $F$. variegata wood is suitable for sawn timber, plywood and face veneer (Sumarni et al. 2009). It has the prospect to be developed for Industrial Plantation Forest (HTI) both with monoculture and mixed patterns (Effendi and Mindawati 2015). Further genetic improvement of the trait such as growth rate (include height and diameter), stem form and wood quality were anticipated to meet rising demand for forest product. The effect of using genetically improved forest plant material is the forest grows faster, the harvests come earlier and the rotation time can be shortened (Haapanen et al. 2015). To initiate a genetic improvement program, progeny trials of the species have been established in Yogyakarta in 2012 by The Centre for Forest Biotechnology and Tree Improvement. Success of breeding programs depends on precise estimates of genetic parameters, including reliable predictions of breeding values (Klápště et al. 2007).

Prediction of breeding values for selection of superior genetic material is a major problem in tree breeding program. Breeding value represents the genetic value of the individual based on the performance of individuals and the mean of its relatives (Falconer and Mackay 1996). Predicted breeding values can be used to rank families, identifying the best genotypes in either seedling or clonal seed orchards; and utilization of seeds for operational scale planting (White 1996). Accuracy of the predicted breeding values is therefore important to maximize the genetic gain in a breeding program (White and Hodge 1987; White 1996). Restricted Maximum Likelihood (REML) and Best Linear Unbiased Prediction (BLUP) methods are an efficient method to identify individuals to obtain maximum genetic gain (Klápšstě et al. 2007). This method has been widely used in several perennial and annual species (Oliveira et al. 2014).

The objective of this study was to estimate genetic gain of various selection scenarios of $F$. variegata based on breeding value using REML/BLUP methods.

\section{MATERIALS AND METHODS}

\section{Study site and plants materials}

The study site is located in Bantul, Yogyakarta Province (latitude S $07^{\circ} 57^{\prime} 30^{\prime \prime}-07^{\circ} 57^{\prime} 54^{\prime \prime}$, longitude E $110^{\circ} 26^{\prime} 07^{\prime \prime}-110^{\circ} 26^{\prime} 29^{\prime \prime}$, average altitude of $75 \mathrm{~m}$ above sea level). Elevation of the site is between $5 \%-30 \%$, and the soil in the area is classified as oxisol. The climate of the 
region according to the Köppen classification is $A f$ (tropical rain forest climate) to $\mathrm{Am}$ (tropical monsoon climate) type, or type $\mathrm{C}$ (medium wet) of climate classification by Schmidt and Ferguson, with mean annual rainfall of 1,502 mm (Bappeda Kabupaten Bantul 2011).

\section{Materials}

The progeny trial established in December 2012 comprised of 595 individual trees from 17 families of $F$. variegata collected from West Nusa Tenggara Province, Indonesia. The progeny test was set up in randomized complete blocks with 17 progenies (treatments), 5 tree plots and 7 replications in a spacing of $5 \times 5 \mathrm{~m}$. Details of the site where genetic materials were collected are presented in Table 1.

The measurement of three years old of $F$. variegata to assess growth performance (tree height and diameter). Height was measured from the ground to the tip of the tree, and stem diameter was measured at $1.3 \mathrm{~m}$ above ground (DBH).

\section{Data analysis}

The raw field data were initially logged into an Excel spreadsheet. Screening outlier data was performed prior to statistical analysis, leaving 465 data of individual trees of 17 families. The following linear model was used to describe the observed values, including fixed and random factors, appropriate for the mixed-model methodology:

$$
\mathrm{Y}=\mathrm{X} \beta+\mathrm{Z} \mu+\mathrm{e}
$$

\section{Where:}

$\mathrm{Y}-\mathrm{n} \times 1$ vector of observations,

$\mathrm{X}-\mathrm{n} \times \mathrm{p}$ design matrix for fixed effects,

$\beta-p \times 1$ vector of fixed effects,

$\mathrm{Z}-\mathrm{n} \times \mathrm{q}$ design matrix for a $\mathrm{q} \times 1$ vector of random effects $\boldsymbol{\mu} \sim \mathrm{N}(0, \mathrm{G})$,

$\mathrm{e} \sim \mathrm{N}(0, \mathrm{R})-\mathrm{n} \times 1$ vector for residuals, and

$$
\operatorname{Var}\left[\begin{array}{l}
\mathrm{u} \\
\mathrm{e}
\end{array}\right]=\left[\begin{array}{ll}
\mathrm{G} & 0 \\
0 & \mathrm{R}
\end{array}\right] \sigma^{2}
$$

Where:

$\mathrm{G}, \mathrm{R}$ : Positive definite variance-covariance matrices $\sigma^{2} \quad$ : Positive constant

Consequently, $\mathrm{Y}$ is $\mathrm{n} \times 1$ vector of observations and it is assumed to be distributed:

$$
\mathrm{Y} \sim \mathrm{N}(\mathrm{X} \beta, \mathrm{R}+\mathrm{ZGZ})
$$

Variance components of each trait were estimated by REML procedure (Lynch and Walsh 1998). G and R were estimated by BLUP procedure which provides the best linear unbiased estimator $\left(\beta^{\wedge}\right)$ of $\beta$ and the best linear unbiased predictor $\left(\mu^{\wedge}\right)$ of $\mu$. Values random effects (family) were predictive value GCA (General Combining Ability) the family.

Family breeding value was calculated by the following equation (Falconer and Mackay 1996):

$$
\left(\mathrm{BV}_{\mathrm{HS}}\right)=2 \mathrm{GCA}
$$

Where:

$\mathrm{BV}_{\mathrm{HS}}$ : Family breeding value

Individual breeding value (IBV) was calculated by combining parental and family breeding value components. Linear model of the equation was described by Xiang and Li (2001):

$$
\mathrm{IBV}=\mathrm{BV}_{\mathrm{HS}}+\mathrm{Aw}
$$

Where:

Aw : Deviation within family, calculated by the following formula:

$A w=\frac{3 \sigma_{\mathrm{f}}^{2}}{\sigma_{\mathrm{e}}^{2}}\left(y-X \beta^{\wedge}-\mathrm{Zu}\right)$

Where:

$\sigma_{f}^{2}$ : Variance component of family

$\sigma^{2}{ }_{e}$ : Variance component of error

$\frac{3 \sigma_{\mathrm{f}}^{2}}{\sigma_{\mathrm{e}}^{2}}=$ within family heritability

Estimation of individual heritability (narrow-sense individual heritability) determined by use of the following formulae (Zobel and Talbert 1984):

$$
\mathrm{h}_{\mathrm{i}}^{2}=\frac{4 \sigma_{\mathrm{f}}^{2}}{\sigma_{\mathrm{e}}^{2}+\sigma_{\mathrm{fb}}^{2}+\sigma_{\mathrm{f}}^{2}}
$$

Where:

$\mathrm{h}_{\mathrm{i}}^{2}$ : Individual heritability

$\sigma_{f}^{2}$ : Variance component of family

$\sigma_{f b}^{2}$ : Variance component of family $\mathrm{x}$ block interaction

$\sigma_{e}^{2}$ : Variance componen of error

Table 1. Details of the seed source of Ficus variegata in West Nusa Tenggara Province, Indonesia

\begin{tabular}{llclll}
\hline Seed source & Geographical position & $\begin{array}{l}\text { Altitude } \\
(\mathbf{m} \text { asl })\end{array}$ & Soil type & $\begin{array}{l}\text { Annual } \\
(\mathbf{m m})\end{array}$ & rainfall Climate \\
\hline West Nusa Tenggara & $\begin{array}{l}\text { S } 08^{\circ} 22^{\prime} 44^{\prime \prime}-08^{\circ} 32^{\prime} 19^{\prime \prime} ; \\
\text { E 116 } 14^{\prime} 01^{\prime \prime}-116033^{\prime} 52^{\prime \prime}\end{array}$ & $413-1100$ & $\begin{array}{l}\text { Andosol and brown } \\
\text { regosol }\end{array}$ & $1500-2000$ & $\mathrm{C}-\mathrm{D} *)$ \\
\hline
\end{tabular}

Note: The climate is according to Schmidt and Ferguson classification (1951); *) BKSDA_NTB (2010) 
Genetic correlation between traits are determined by following formulae (Zobel and Talbert 1984):

$$
r_{G}=\frac{\sigma_{f(x y)}}{\sqrt{\sigma_{f(x)}^{2} \cdot \sigma_{f(y)}^{2}}}
$$

Where:

$\mathrm{r}_{\mathrm{G}}:$ : Genetic correlation

$\sigma_{\mathrm{f}(\mathrm{xy})}$ : Covariance components of $\mathrm{x}$ and $\mathrm{y}$ traits

$\sigma_{f(x)}^{2}$ : Variance component of family for $\mathrm{x}$ traits

$\sigma_{\mathrm{f}(\mathrm{y})}^{2}:$ Variance component of family for $\mathrm{y}$ traits

\section{Prediction of genetic gain}

Given the ranking of both $\mathrm{BV}_{\mathrm{HS}}$ and IBV, it is possible to predict genetic gain under scenarios of selection. Selection strategy was based on families and within family selection. Average of individual breeding values of selected trees from selected families were considered as genetic gain.

The effective population size $(\mathrm{Ne})$ was estimated as follows (Resende 2002):

$$
\mathrm{Ne}=\frac{4 \mathrm{Nf} . \mathrm{kf}}{\left[\mathrm{kf}+3+\left(\frac{\sigma_{\mathrm{kf}}^{2}}{\mathrm{kf}}\right)\right]}
$$

Where:

Nf : Number of selected family;

kf : Mean of selected individual trees per family;

$\sigma^{2}{ }_{\mathrm{kf}}$ : variance of number of selected individual trees per family
Inbreeding rate per generation $(\Delta \mathrm{F})$ was calculated using Falconer and Mackay (1996):

$$
\Delta \mathrm{F}=\frac{1}{2 \mathrm{Ne}}
$$

\section{RESULTS AND DISCUSSION}

\section{Results}

The estimation of variance component and heritability for height and stem diameter is presented in Table 2 . Variance component of family for height contributed to $6.72 \%$ of total variance, while only $5.18 \%$ for diameter.

Individual heritability for height $(0.27)$ and diameter (0.21) There is strong genetic correlation between height and diameter (0.90).

\section{Genetic gain prediction}

Only diameter traits were used in BLUP analysis due to strong genetic correlation between diameter and hight $\left(\mathrm{r}_{\mathrm{G}}=0.9\right)$. BLUP analysis has predicted both family and individual breeding value (Figure 1).

There are seven families which breeding value below population meanwhile 10 families are above (Figure 1).

Family rank presented in Figure 2 shows that family no. 3 , 6 and 2 are the best three of family dominating individual number (78 of 200 individual trees or $39 \%$ ).

The combination of family selection continued by individual selection is presented in Table 3 .

Table 2. Variance component, heritability and genetic correlation for height and stem diameter of Ficus variegata

\begin{tabular}{llllll}
\hline Traits & o2f & o2fb & o2e & hi2 & rG \\
\hline Height & $0.0788(6.72 \%)$ & $0.1762(15.02 \%)$ & $0.9181(78.26 \%)$ & 0.27 & 0.9 \\
Diameter & $0.33(5.18 \%)$ & $1.02(16.01 \%)$ & $5.02(78.80 \%)$ & 0.21 &
\end{tabular}

Note: $\sigma_{f}^{2}$ : Variance component of family; $\sigma_{f b}^{2}$ : Variance component of family and block interaction; $\sigma_{e}^{2}$ : Variance component of residual; $\mathrm{h}_{\mathrm{i}}^{2}$ : individual heritability; $\mathrm{r}_{\mathrm{G}}$ : genetic correlation
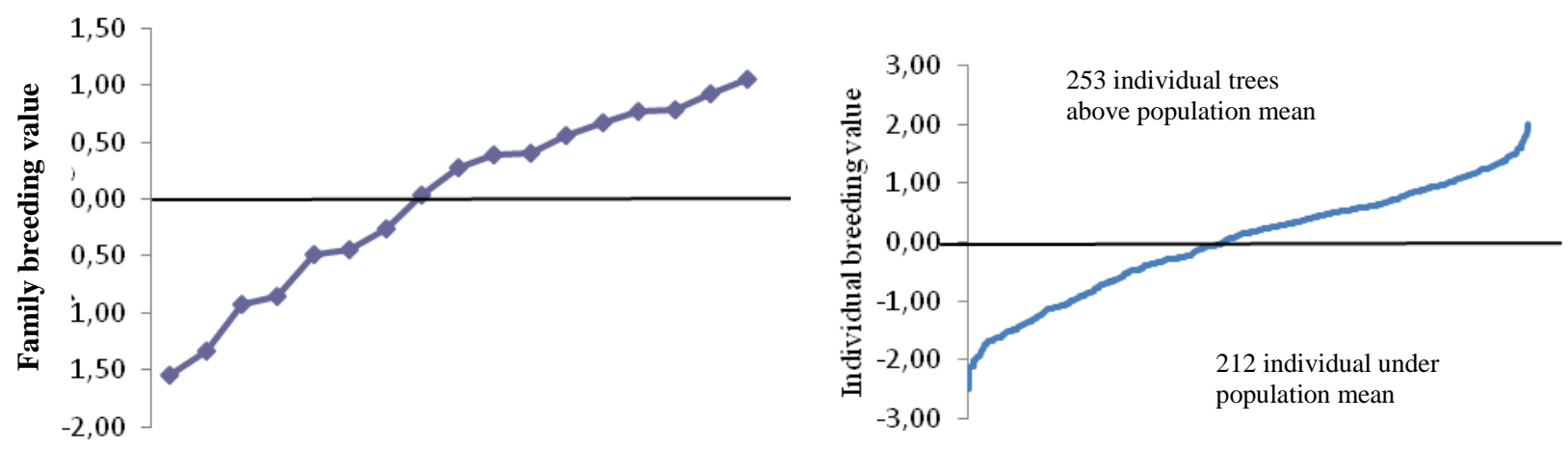

Figure 1. Family breeding value (left) and individual breeding value (right) for stem diameter of Ficus variegata 
Table 3. Genetic gain based on family and individual selection for stem diameter of Ficus variegata at 3 years

\begin{tabular}{|c|c|c|c|c|c|c|c|}
\hline $\mathbf{N}_{\mathbf{f}}$ & $\mathbf{J} / \mathbf{F}$ & $\mathbf{N}$ & $\mathrm{X}_{1}(\mathrm{~cm})$ & $\mathbf{G}(\mathrm{cm})$ & $\mathbf{G}(\%)$ & $\mathrm{Ne}$ & $\Delta \mathrm{F}(\%)$ \\
\hline \multirow[t]{3}{*}{15} & 15 & 225 & 8.33 & 0.50 & 6.38 & 50.00 & 1.00 \\
\hline & 10 & 150 & 8.47 & 0.64 & 8.17 & 46.10 & 1.08 \\
\hline & 5 & 75 & 8.65 & 0.82 & 10.47 & 37.50 & 1.33 \\
\hline \multirow[t]{3}{*}{10} & 15 & 150 & 8.76 & 0.93 & 11.88 & 33.33 & 1.50 \\
\hline & 10 & 100 & 8.90 & 1.07 & 13.66 & 30.76 & 1.62 \\
\hline & 5 & 50 & 9.07 & 1.24 & 15.83 & 25.00 & 2.00 \\
\hline \multirow[t]{3}{*}{5} & 15 & 75 & 9.04 & 1.21 & 15.45 & 16.66 & 3.00 \\
\hline & 10 & 50 & 9.18 & 1.35 & 17.24 & 15.38 & 3.25 \\
\hline & 5 & 25 & 9.35 & 1.52 & 19.41 & 12.50 & 4.00 \\
\hline
\end{tabular}

$\mathrm{N}_{\mathrm{f}}$ : number of selected family; J/F: number of individual trees per family; $\mathrm{N}$ : number of selected individual trees; $\mathrm{X}_{1}$ : average of selected individual trees within selected family; $\mathrm{G}$ : genetic gain; $\mathrm{X}_{0}$ : average of population; Ne: effective population size; $\Delta \mathrm{F}=$ change inbreeding per generation

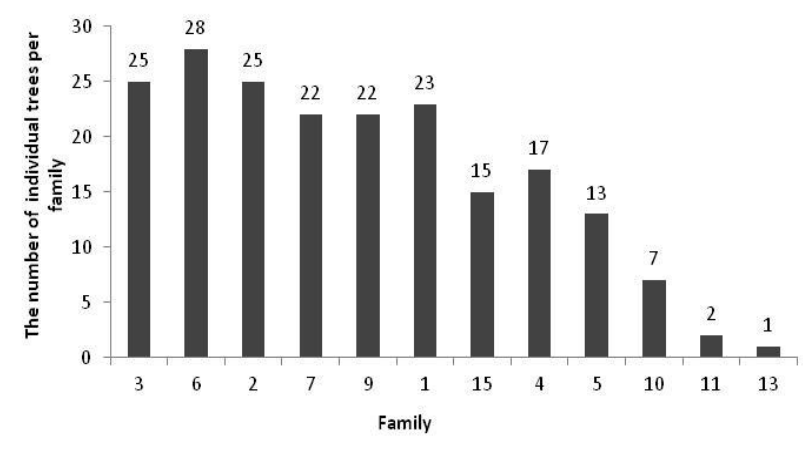

Figure 2. The number of individual trees per family of the best 200

\section{Discussion}

The estimation of variance component for height and stem diameter approximately 5\%. It means that genetic contribution of height and diameter of $F$. variegata is approximately $5 \%$. This value is lower than the genetic contribution of other species such as $\pm 10 \%$ for Eusideroxylon zwageri Teijsm. \& Binn. (the Lauraceae family) (Prastyono and Susanto 2015), $\pm 10 \%$ for Alstonia scholaris R.Br (the Apocynaceae family) (Mashudi and Baskorowati 2015), $\pm 16 \%$ for Melaleuca cajuputi Powell (the Myrtaceae family) (Susanto 2008) but slightly higher than Falcataria mollucana (Miq.) Barneby \& J.W. Grimes (the Fabaceae family) $4 \%$ as reported by Susanto et al. (2014) and Anthocephalus macrophyllus Roxb. (the Rubiaceae family) $4.8 \%$ as reported by Surip et al. (2017).

Heritability is the proportion of variation in the population that is attributable to genetic differences among the individuals. Heritability is of key importance in estimating gains that can be obtained from selection programs (Zobel and Talbert 1984). Individual heritability for height (0.27) and diameter (0.21) calculated is categorized as moderate (Cotterill and Dean 1990). Furthermore, White et al. (2007) mentioned that heritability estimation based on one location trial for stem growth is $0.1-0.3$. In tree improvement program, the appropriate selection method for plant with moderate heritability is family selection, within family selection or both combination. (Matheson and Raymond 1994; Matziris 2005; Fries and Ericsson 2006).

There is strong genetic correlation between height and diameter (0.90). It can be assumed that improving diameter will concurrently improve height and vice-versa. This correlation is higher than that reported by Weng et al. (2007) on 5 years old of Pinus banksiana Lamb (the Pinaceae family) (0.78), Adinugraha et al. (2013) on 5 years old Tectona grandis L.f (the Verbenaceae family) (0.83) ) and Sumardi et al. (2018) on Melaleuca cajuputi subsp. cajuputi Powell (the Myrtaceae family ) (0.57) but slightly lower than Anthocephalus macrophyllus Roxb. (the Rubiaceae family) on 40 months (0.99) as reported by Surip et al. (2017).

\section{Genetic gain prediction}

Genetic gain is response due to selection activities. Genetic gain was calculated based on the average population before and after selection was performed. The selection is based upon the principle that the average genetic value of selected individual will be better than the average value of individuals in the population as a whole (Zobel and Talbert 1984).

Only diameter traits were used in BLUP analysis due to strong correlation between diameter and hight $\left(\mathrm{r}_{\mathrm{G}}=0.9\right)$. BLUP analysis has predicted both family and individual breeding value show that there are seven families which breeding value below population meanwhile 10 families. This indicates that $58.82 \%$ of families from West Nusa Tenggara are likely to inherited good traits to their offspring. Breeding value of family is determined by General Combining Ability (GCA). It means that proper crossing among families in natural habitat exists, hence the offspring have good quality in diameter. This is probably due to the high outcrossing rate of this species $(\mathrm{tm}=1)$, so able to maintain genetic diversity in offspring (Nurtjahjaningsih et al. 2019). Distribution of family and individual breeding value for stem diameter has a similar pattern. But, the amount of individual number that has the breeding value more than population is $54.40 \%$ of total individual tested. This shows that the families that have an 
average value above the average population are not necessarily all descendants of the tree has a value above the average breeding population in the descent test. This condition is due to within family heritability. The heritability is 0.20 means genetic variation within families is high. The variation is gained from outcrossing system among families that compatible verified from previous GCA calculation.

Family rank presented in Figure 2 shows that if the selection is based on individual rank, the next generation will be dominated by small number of family with high inbreeding potential. Using information from family members implies that members of the same (good) family have more chance to be jointly selected (Belonsky and Kennedy 1988). This will impact to choose a strategy relating to effective population size and tolerable inbreeding rate. Breeding level needs to be maintained for long term breeding strategy because the higher in breeding level, the higher risk of genetic variation lost for next generation and the potential of inbreeding depression (White et al. 2007), therefore it is very important to maintain between genetic gain and relatedness.

Further selection (in Table 3 ) is to undertake the family selection continued by individual selection within family with the same number per family (Cotterill and Dean 1990). The combination of family selection continued by individual selection is more accurate and resulted high genetic gain compare to among family selection, whether within family selection or mass selection (Magnussen and Yeatman 1990; Filho and Vencovsky 2000). Selection of the best 15 families and family size of 15 individual trees has the lowest inbreeding level (1\%) per year, even though genetic gain obtained is low $(6.38 \%)$. Selection of the best 10 families with 5 individual trees of family size is the best option because of genetic gain resulted in $15.83 \%$ with inbreeding level $2 \%$ per generation. Despite selection from the best five families with 5 individual of family size contributed to the highest genetic gain, but inbreeding level up to $4 \%$ per generation. Keiding (1993) mentioned that the average of inbreeding $1-2 \%$ are accepted. Genetic gain of diameter will significantly increase stem volume of $F$. variegata due to the strong correlation between diameter and volume is 0.96 (Qirom and Supriyadi 2013).

In conclusion, genetic improvement for $F$. variegata is possible with the estimation of genetic variance components families (height and diameter) $\pm 5 \%$ total variance while individual heritability of height and diameter are moderate. Selection is quite easy to do in diameter. BLUP analysis for properties in diameter trait results in selection of the best individuals from the best families with restrictions 10 families with 5 individual/tree per family is an optimal choice with the prediction of genetic gain of $15.83 \%$ with a $2 \%$ rate of inbreeding per generation.

\section{ACKNOWLEDGEMENTS}

We thanks to Director of Centre for Forest Biotechnology and Tree Improvement Research, The
Ministry of Environment and Forestry, Indonesia for fully supporting this study.

\section{REFERENCES}

Adinugraha HA, Pudjiono S, Mahfudz. 2013. Variasi pertumbuhan dan parameter genetik uji keturunan jati umur 5 tahun di Gunungkidul, Yogyakarta. J Pemuliaan Tanaman Hutan 7 (3): 167-178. [Indonesian]

Bappeda Kabupaten Bantul. 2011. RPJMD Kabupaten Bantul 2011-2015. Bappeda Kabupaten Bantul. [Indonesian]

Belonsky GM, Kennedy BW. 1988. Selection on individual phenotype and best linear unbiased predictor of breeding value in a closed swineherd. J Anim Sci 66 (5): 1124-1131.

BKSDA NTB. 2010. Panduan Wisata Alam di Kawasan Konservasi Nusa Tenggara Barat. http://ekowisata.org/wpcontent/uploads/2011/03/Panduan-Wisata-BKSDA-NTB [Indonesian]

Cotterill PP, Dean CA. 1990. Successful Tree Breeding with Index Selection. CSIRO Division of Forestry and Forest Product, Canberra, Australia.

Effendi R, Mindawati N. 2015. Budidaya Jenis Pohon Nyawai (Ficus variegata Blume). Pusat Penelitian dan Pengembangan Hutan, Badan Penelitian, Pengembangan dan Inovasi Kementerian Lingkungan Hidup dan Kehutanan. [Indonesian]

Falconer DS, Mackay TFC. 1996. Introduction to Quantitative Genetics. Longman, Edinburgh.

Filho JSS, Vencovsky R. 2000. Efficiency of combined selection over sequential selection in forest tree progeny trials. Silvae Genet 49: $169-173$.

Fries A, Ericsson T. 2006. Estimating genetic parameter for wood density of Scot pine (Pinus sylvestris L.). Silvae Genet 55 (2): 84-92.

Haapanen M, Jansson G, Nielsen UB, Steffenrem A, Stener LG. 2015. The status of tree breeding and its potential for improving biomass production. Gävle Offset, Gävle.

Keiding H. 1993. Gene conservation and tree improvement. Lecture Note D-9. Danida Forest Seed Centre, Humlebaek, Denmark.

Klápště J, Lstibůrek M, Kobliha J. 2007. Initial evaluation of half-sib progenies of Norway spruce using the best linear unbiased prediction. J For Sci (41130): 41-46.

Kuaraksa C, Elliott S, Hossaert-McKey M. 2012. The phenology of dioecious Ficus spp. tree species and its importance for forest restoration projects. For Ecol Manag 265: 82-93.

Lynch M, Walsh B. 1998. Genetics and Analysis of Quantitative Traits. Sinauer Associates, Inc., Sunderland, MA.

Magnussen S, Yeatman CW. 1990. Predictions of genetic gain from various selection methods in open pollinated Pinus banksiana progeny trials. Silvae Genet 39: 140-153.

Mashudi, Baskorowati L. 2015. Estimasi parameter genetik pada uji keturunan Alstonia scholaris umur dua tahun di Gunungkidul, Yogyakarta. J Pemuliaan Tanaman Hutan 9 (1): 1-12. [Indonesian]

Matheson AC, Raymond CA. 1994. Effects of thinning in progeny test on estimates of genetic parameters in Pinus radiata. Silvae Genet 33 (4): 125-128.

Matziris D. 2005. Genetic variation and realized genetic gain from Black pine tree improvement. Silvae Genet 54 (3): 96-104.

Nurtjahjaningsih ILG, Haryjanto L, Sulistyawati P, Widyatmoko AYPBC. 2019. Mating system of two priority species for ecosystem restoration at Mount Merapi. AIP Conference Proceedings 2120, 040028. DOI: 10.1063/1.5115666

Oliveira EJ, Santana FA, Oliveira LA, Santos VS. 2014. Genetic parameters and prediction of genotypic values for root quality traits in cassava using REML / BLUP. Genet Mol Res 13 (3): 6683-6700.

Prastyono, Susanto M. 2015. Variasi sifat pertumbuhan ulin (Eusideroxylon zwageri T. et B.) pada uji keturunan di Bondowoso. J Wasian 2 (2): 79-86. [Indonesian]

Qirom MA, Supriyadi. 2013. Model penduga volume pohon nyawai (Ficus variegate Blume) di Kalimantan Timur. J HutanTanaman 10 (4): 173-184. [Indonesian]

Resende MDV. 2002. Genética Biométrica e Estatística no Melhoramentode Plantas Perenes. Embrapa Informação Tecnológica, Brasília, 975 pp.

Schmidt FH, Ferguson JHA. 1951. Rainfall Types Based on Wet and Dry Period Ratios for Indonesia with Western New Guinee. Kementerian 
Perhubungan, Djawatan Meteorologi dan Geofisik Republik Indonesia, Jakarta.

Spencer H, Weibleni G, Flick B. 1996. Phenology of Ficus variegate in a seasonal wet tropical phenology of Ficus variegata at forest Cape Tribulation, Australia. J Biogeogr 23: 467-475.

Sumardi, Kartikawati NK, Prastyono, Rimbawanto A. 2018. Selection and genetic gain observed at second generation progeny trial of cajuput (Melaleuca cajuputi subsp. cajuputi) in Gunungkidul. J PemuliaanTanaman Hutan 12 (1): 65-73. [Indonesian]

Sumarni G, Muslich M, Hadjib N, Krisdianto, Malik D, Suprapti S, Basri E, Pari G, Iskandar MI, Siagian RM. 2009. Sifat dan Kegunaan Kayu: 15 Jenis Andalan Setempat Jawa Barat. Pusat Penelitian dan Pengembangan Hasil Hutan, Bogor. [Indonesian]

Surip, Indrioko S, Nirsatmanto A, Setyaji T. 2017. Effect of selection on genetic gain of first-generation seedling seed orchards of jabon merah (Anthocephalus macrophyllus (Roxb.) Havil) established in Wonogiri. J PemuliaanTanaman Hutan 11 (1): 33-44. [Indonesian]

Susanto M. 2008. Analisis komponen varian uji keturunan Melaleuca cajuputi subsp. cajuputi di Paliyan, Gunungkidul. J Penelitian Hutan Tanaman 5 (1): 199-264. [Indonesian]

Susanto M., Baskorowati L. Setiadi D. 2014. Estimasi peningkatan Genetik Falcataria moluccana di Cikampek Jawa Barat. J Penelitian Hutan Tanaman 11 (2): 65-76. [Indonesian]
Weng YH, Tosh KJ, Park YS, Fullarton MS. 2007. Age-age trends in genetic parameters for Jack pine and their implications for early selection. Silvae Genet 56 (5): 242-251.

White TL, Adams WT, Neale DB. 2007. Forest Genetics. CABI Publishing, Wallingford, UK

White TL, Hodge R. 1987. Practical uses of breeding values in tree improvement programs and their prediction from progeny test data. Proc. 191h South For. Tree Improve Conf. College Station, Texas A\&M Univ., TX.

White TL. 1996. Genetic parameter estimates and breeding value predictions: issues and implications in tree improvement programs. In: Dieters MJ, Matheson AC, Nickles DG, Hardwood CE, Walker SM (eds) Tree Improvement for Sustainable Tropical Forestry; Proc. QFRI-IUFRO Conf. Caloundra. Queensland, Australia, 27 Oct.-1 Nov 1996.

Xiang B, Li B. 2001. A new mixed analytical method for genetic analysis of diallel data. Can J For Res 31: 2252-2259.

Zhou Z, Gilbert MG. 2003. Moraceae. In: Wu ZY, Raven PH. (eds.). Flora of China, Vol. 5. Science Press, Beijing.

Zobel B, Talbert J. 1984. Applied Forest Tree Improvement. John Willey and Sons, New York. 